\title{
Propionibacteria and their role in the biological control of aerobic spoilage in silage
}

\author{
Roger J. Merry*, David R. Davies
}

Institute of Grassland and Environmental Research, Plas Gogerddan, Aberystwyth, Ceredigion, SY23 3EB, United Kingdom

\begin{abstract}
Silage fermentation has been the subject of much research both on factors influencing the efficiency of preservation and biotechnological approaches to manipulate what is essentially an uncontrolled process. However, although the predictability of the fermentation and, consequently, silage quality has been improved, there is increasing evidence that high quality silages are extremely susceptible to spoilage by the activity of aerobic micro-organisms on opening the silo. The main biological approach to manipulate the fermentation has involved the use of homofermentative strains of lactic acid bacteria as inoculants to direct the fermentation towards lactic acid production and rapid $\mathrm{pH}$ decline and there is some evidence that this exacerbates the problem of aerobic spoilage. Several microbial groups have been implicated in spoilage including yeasts, moulds, acetic acid bacteria and Bacillus species. The consensus of opinion, however, is that the yeasts are in most cases the primary initiators of spoilage, with bacteria having an involvement depending on conditions. Species of the genus Propionibacteria have been singled out as potential silage inoculants to combat aerobic spoilage because propionic acid is a very effective antimycotic at the low $\mathrm{pH}$ of good silage when a high proportion of this acid is in the undissociated state. Several Propionibacteria species have been isolated from silage and a limited number of experiments carried out using them as silage inoculants, but the findings are equivocal. This paper reviews the area of silage fermentation, aerobic stability of silage and the potential of propionibacteria as biocontrol agents for silage. (C) Inra/Elsevier, Paris.
\end{abstract}

\section{silage / aerobic stability / yeast / inoculant / propionibacteria}

Résumé - Les bactéries propioniques et leur rôle dans le contrôle biologique de l'altération aérobie de l'ensilage. La fermentation de l'ensilage a fait l'objet de nombreuses recherches tant sur les facteurs influençant la qualité de la conservation que sur les approches biotechnologiques pour diriger ce qui reste un procédé non-contrôlé. Cependant, bien que la prédictabilité de la fermentation et en conséquence la qualité de l'ensilage aient été améliorées, il est évident que les ensilages de haute qualité sont très sensibles aux altérations dues à l'activité de microorganismes aérobies à l'ouverture du silo. La principale approche biologique pour diriger la fermentation a mis en œuvre l'utilisation de souches de bactéries lactiques homofermentaires inoculées pour conduire la fermentation vers la production d'acide lactique et une baisse rapide du $\mathrm{pH}$, mais cela augmente le risque de

Oral communication at the 2nd Symposium on Propionibacteria, Cork, Ireland, June 25-27, 1998.

* Correspondence and reprints. Roger.Merry@bbsrc.ac.uk 
problème d'altération aérobie. Plusieurs groupes microbiens sont impliqués dans l'altération, dont des levures, des moisissures, des bactéries productrices d'acide acétique et des Bacillus. Cela dit, on s'accorde à considérer que les levures sont dans la plupart des cas les initiatrices primaires de l'altération, avec l'implication de bactéries selon les conditions. Les espèces du genre Propionibacterium ont été choisies pour un ensemencement potentiel de l'ensilage afin de combattre les dégradations aérobies car l'acide propionique est un antifongique puissant au bas $\mathrm{pH}$ d'un ensilage de qualité, lorsqu'une forte proportion de cet acide est sous forme non-dissociée. Plusieurs espèces de bactéries propioniques ont été isolées d'ensilages et quelques expériences d'ensemencement d'ensilage par ces bactéries propioniques ont été réalisées, mais les résultats sont équivoques. Cette revue fait le point sur la fermentation en ensilage, la stabilité aérobie de l'ensilage et le potentiel des bactéries propioniques comme agents de biocontrôle pour l'ensilage. (O) Inra/Elsevier, Paris.

\section{ensilage / stabilité aérobie / levure / ensemencement / bactérie propionique}

\section{INTRODUCTION}

Silage is the feedstuff produced by the fermentation of forage crops of variable but often high moisture content. The objective of ensilage is to preserve forage, when it is abundant, for feeding livestock when fresh material is less available. When successful, silage fermentation is a natural process whereby epiphytic lactic acid bacteria ferment water soluble carbohydrates (WSC) in the crop to a number of products, primarily lactic acid, thereby reducing the $\mathrm{pH}$ as rapidly as possible, inhibiting spoilage microbes and preserving the maximum amount of nutrients in the product. Since the early 1950 's, both the quantity of forage produced and the proportion that is preserved as silage have increased. In contrast to hay-making, it is much less weatherdependent and is also adaptable to a wide range of crops, including grass, cereals, legumes and root crops. In Europe, an estimated 160 million tonnes of forage dry matter are ensiled annually [73].

With the gradual increase in the popularity of silage, much research has concentrated on the manipulation of fermentation to improve its quality. Paradoxically, although this has led to improvements in silage quality, its instability after the silo is opened and exposed to air appears to increase and has become a significant problem. Woolford [79] described the presence of air as the
'Achilles heel' of the ensilage process and although several microbial groups have been implicated in the aerobic spoilage of silage, yeasts appear to be the primary initiators $[40,80]$. The reduction in silage quality and losses of feed dry matter due to this phenomenon can be high, with the latter being as high as $25 \%$ in bunker silos [77, 80], and has been estimated to cost the UK farming industry $£ 110$ million per annum [74]. To appreciate why interest has been generated in propionibacteria as biocontrol agents, an overview of silage fermentation and the sequence of events leading to aerobic deterioration in silage is appropriate.

\section{THE ENSILAGE PROCESS}

The ensilage process can be divided into 3 distinct phases: the initial aerobic phase, the fermentation phase and a second aerobic phase when the silo is opened, each having consequences for the quality of the product that is fed to livestock. A scheme is presented that shows the microbial groups found in ensiled herbage and silage that is undergoing aerobic spoilage (figure 1). The horizontal division separates facultative and obligate anaerobes primarily involved in fermentation (upper segment) from obligate aerobes and facultative anaerobes which may play a role when air enters the silo or the feed manger (lower segment). Central 


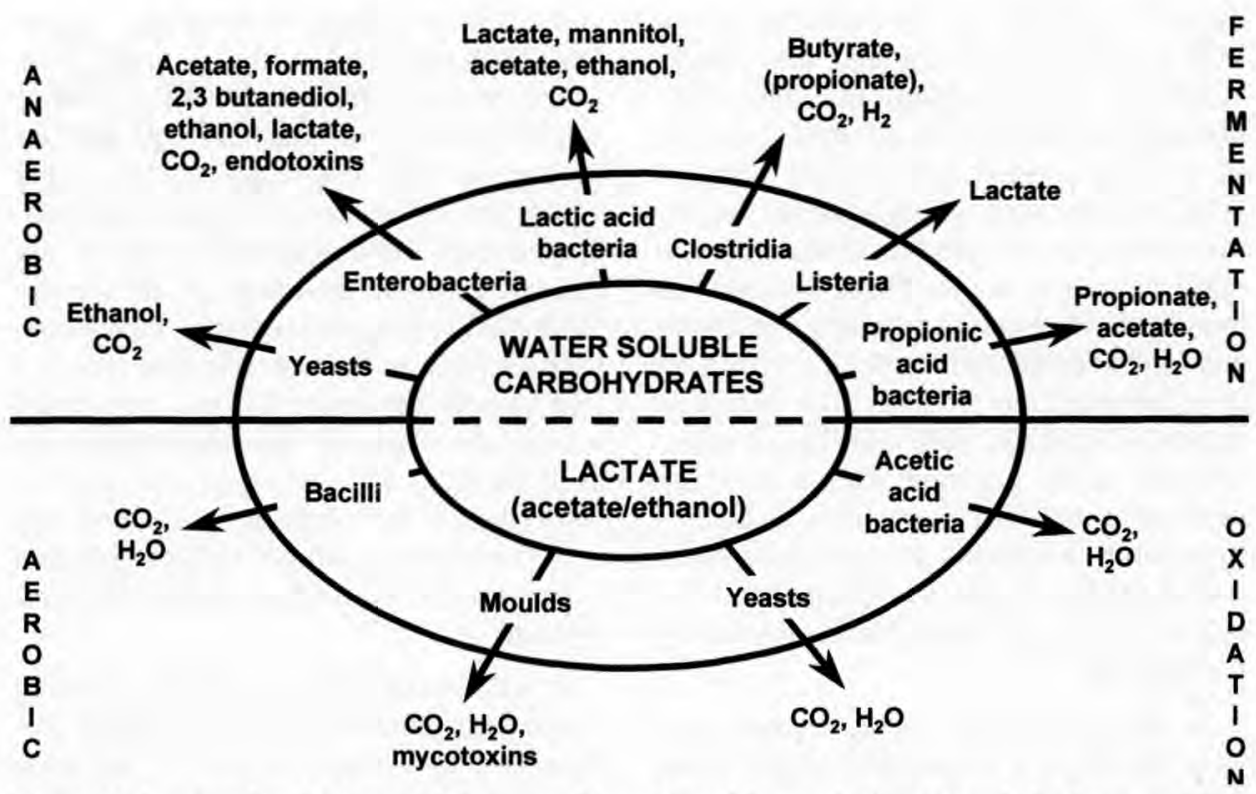

Figure 1. A generalized scheme of the anaerobic and aerobic metabolism of carbohydrates and fermentation products by forage micro-organisms (adapted from: Day and Liscansky [15]).

Figure 1. Schéma général du métabolisme anaérobie et aérobie des sucres et produits de la fermentation par les microorganismes du fourrage (adapté de Day et Liscansky [15]).

to the anaerobic phase of the scheme are the WSC, which in grass mainly comprise a mixture of fructans $(\beta, 2-6$ linked polymers of fructose), fructose, glucose and sucrose and are the substrates that fuel the fermentation. In other crops such as maize and legumes, fructans may be replaced by starch as the storage polysaccharide, although starch is not fermented by most lactic acid bacteria (LAB). The efficiency with which WSC are used for lactic acid production, rather than oxidation or fermentation to other products that are less effective at lowering $\mathrm{pH}$, influences the quality of the final silage. Also shown in figure 1 are the main products of fermentation, which are oxidized to $\mathrm{CO}_{2}$ and $\mathrm{H}_{2} \mathrm{O}$ when air enters the silage.

\subsection{The aerobic phase}

A major factor which influences the efficiency with which forages are conserved as silage is the degree of anaerobiosis achieved in the silo [80]. Initially, air trapped in the herbage matrix fuels aerobic processes, including both plant respiration which continues after harvesting and undesirable bacterial and fungal activity. Good ensiling practice includes rapid sealing of the silo, which will play a role in shortening the initial aerobic phase [40]. It will also reduce the chances of large fungal populations developing and compromising the aerobic stability of the product.

\subsection{The fermentation phase}

A number of both facultative and strictly anaerobic micro-organisms which enter the silo on the forage may be involved in the fermentation, thus a diverse range of products can accumulate in silage in varying concentrations (figure 1, upper segment). During the early stages of the fermentation, 
there is competition for substrate (crop WSC) between the facultative and strictly anaerobic micro-organisms. The most important of the bacterial groups are the lactic acid bacteria ( $\mathrm{LAB}$ ) as they ferment WSC to lactic acid, which achieves the primary objective of the fermentation, i.e. a rapid reduction in $\mathrm{pH}$. These bacteria are broadly divided into two groups: the homoand heterofermentative species, based on their fermentation products. The homofermentative species, which produce 2 molecules of lactate per molecule of sugar are more desirable for preservation, as heterofermentative species also produce compounds such as acetic acid, ethanol and carbon dioxide that are less effective at lowering herbage $\mathrm{pH}$.

In the initial stages of the fermentation when the $\mathrm{pH}$ is $>4.5$, members of the genus Enterobacteria are generally present in fairly high numbers $[62,63,65]$. They are undesirable as they do not contribute usefully to the acidification and preservation process, and their rate of decline in silage is positively correlated with the rate of $\mathrm{pH}$ decline $[42,63]$. The lowering of $\mathrm{pH}$ also inhibits the growth of clostridia, which are strictly anaerobic bacteria involved in the fermentation of WSC and lactic acid to butyric acid and sometimes propionic acids, and the conversion of protein degradation products to ammonia and amines, which ultimately leads to poor quality silage $[40,78]$.

The other group of bacteria that are included in figure $l$ are the propionibacteria. They have occasionally been isolated from silages $[16,75]$ but are not normally major participants in silage fermentation and will be discussed later, in the context of silage inoculants.

Finally, there are the fungi, which grow either as single cells, yeasts, or as multicellular filamentous colonies, moulds [78]. Until fairly recently, there was a general lack of interest in yeasts as they were considered to be a minority group and not major participants in the fermentation. However, under certain conditions, very high counts have been observed in, for example, grass silages treated with high levels of formic or sulphuric acid $[9,25]$ and in silage that has been prepared from wilted forage $[25,31]$ or where the initial aerobic phase was prolonged [60]. Their activity in silage is not considered to be desirable, as their main fermentation product is ethanol, which contributes little to the preservation process. The moulds are generally only associated with silage where air has penetrated, such as at the sides and surface of the clamp or bale, whereas the conditions associated with a well preserved silage, i.e. low $\mathrm{pH}$ and anaerobiosis, are unfavourable for their growth.

It is thus evident that a naturally occurring silage fermentation is an uncontrolled process. One of the major causes is variation in numbers and types of LAB and other micro-organisms entering the silo $[10,41$, 59]. Consequently, a large number of silage additives have been developed to control and improve on the predictability of fermentation [3]. Two major additive groups with opposing objectives have emerged: chemicals such as formic or sulphuric acid and formaldehyde, which inhibit or prevent microbial activity, and those with biological activity, such as inoculants and sources of fermentable substrate such as molasses, which promote microbial activity. Inoculants contain selected homofermentative strains of LAB, which, when applied to herbage at a rate of $10^{5}$ to $10^{6} \mathrm{cfu} \cdot \mathrm{g}^{-1}$ fresh matter, are intended to dominate the fermentation and accelerate the rate of $\mathrm{pH}$ decline [62]. However, they do not necessarily achieve this goal. For health and safety reasons and due to their corrosive effect on farm machinery, chemical additives are becoming less popular despite the fact that silage prepared using acid additives is often more stable on exposure to air $[10,11,17$. 571. On the other hand, inoculants with their environmentally friendly image have dramatically increased in popularity in recent years, as scientific evidence supporting their 
efficacy has increased $[43,70]$ coupled to the resistance of use of acid additives and the practical difficulties of using sugar additives.

\subsection{The feed-out phase and aerobic deterioration}

At feed-out, i.e. the time that the silo is opened and when air gains access to a hitherto anaerobic environment, well preserved, high quality silages with high concentrations of lactic acid and residual WSC are often prone to spoilage [29, 33, 78, 79]. There is some evidence which suggests that the susceptibility of silage to aerobic deterioration is higher in inoculant treated grass $[33,84]$ and cereal silages $[28,61,69,85]$ than in corresponding non-inoculated silages, where heterofermentative LAB and other less desirable micro-organisms have presumably played a greater role in the fermentation. This may in part be related to the fact that the production of lower concentrations of volatile fatty acids $[76,77]$ and antimycotic compounds such as ammonia $[39,78]), \mathrm{CO}_{2}$ and others [35] are suppressed by directing fermentation towards lactic acid production using inoculants. Furthermore, the extent of dissociation of acids is dependent on $\mathrm{pH}$ which has a marked effect on the antimicrobial activity of the acids, where for example acetic acid is more inhibitory than lactic acid at low $\mathrm{pH}$ [35].

The main microbial groups that are associated with aerobic spoilage activity and their products are shown in figure $I$ (lower segment). They include yeasts [32], moulds [27, 40], Bacillus spp. [77] and acetic acid bacteria [66]. Also shown in figure 1 (upper segment) are members of the genus Listeria which increase in numbers at low oxygen concentrations and as silage $\mathrm{pH}$ rises when air enters the silo [21]. Listeria monocytogenes is an opportunist pathogen that causes infection in cattle and sheep [21]. These bacteria are included in the anaerobic phase (upper segment) as they are micro-aerophiles and generally proliferate during the fermentation phase, when low concentrations of oxygen are available after accidental air ingress [21]. Populations of yeasts, moulds and bacteria develop successionally after aeration and the order can vary depending on temporal changes in silage composition and environmental conditions. A typical sequence of events taking place during the aerobic spoilage of maize silage is shown in figure 2 . As microbial oxidation of lactic acid and other products occurs, the $\mathrm{pH}$ rises and the temperature profile changes in response to the proliferation of each microbial group. The results for $\mathrm{pH}$ values and the temperature profiles are shown for two silages, one treated with a biological and the other with a chemical additive (figure 2). Those for an untreated control silage are not shown but the pattern was similar to that for the inoculated silage, which was in marked contrast to the acid treated silage, where the time taken to reach $25^{\circ} \mathrm{C}$ was delayed by $1.25 \mathrm{~d}$. The microbial groups that were active in this silage at different stages are indicated, although the pattern is not common to all silages as acetic acid bacteria do not always play a role in grass silage [66]. However, it is generally recognized that mould numbers increase in the later stages of deterioration, i.e. where the second temperature peak arises and large increases in $\mathrm{pH}$ occur $[4,27,47]$. The production of mycotoxins by moulds has implications for human and animal health [48].

Thus, it is generally accepted that whilst other micro-organisms are involved, yeasts play the major role in initiating the aerobic spoilage of silage [81, 32]. Moreover, Woolford [80] claimed that it is mainly the size and composition of the population of lactate utilizing yeasts that determine whether a silage will deteriorate upon exposure to air. Yeasts with this characteristic can be undetectable on the crop at harvest but after less than $1 \mathrm{~d}$ of wilting in the field can reach a population size of $10^{4}$ colony forming units CFU. $g^{-1}$ FM [32]. Those found in silage are generally divided into 2 groups according 

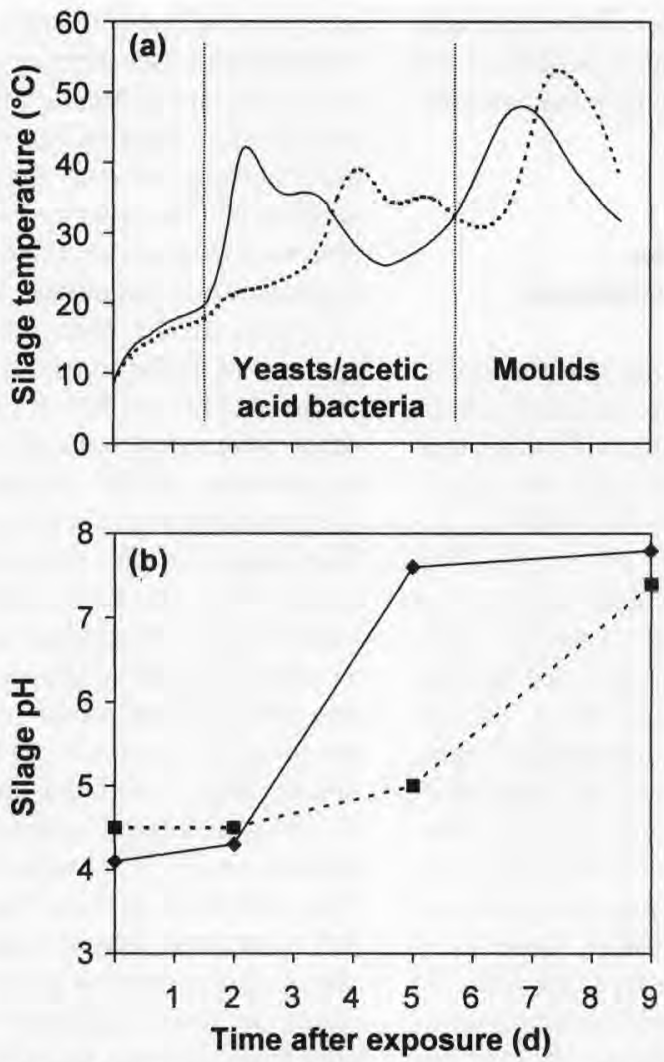

Figure 2. Changes in (a) temperature and (b) $\mathrm{pH}$ during the aerobic deterioration of inoculated $(--)$ and acid treated (……) maize silage (Jones R., Fychan R., Davies D.R., Merry R.J., unpublished data).

Figure 2. Évolution de la température (a) et du pH (b) au cours de l'altération aérobie du maïs (Jones R., Fychan R., Davies D.R., Merry R.J., données non publiées).

to substrate utilization and are either saccharolytic or lactate fermenting $[32,40,45$, 46]. On the other hand, despite these distinctions between groups according to classical laboratory tests, it has been suggested that, if examined under conditions similar to those found in silage, all yeasts can use lactate as a carbon and energy source [46].

Although there is evidence to suggest that silage inoculants decrease the aerobic stability of silage, aerobic spoilage of good quality silage is a major source of loss to farmers irrespective of whether or not an additive has been used [77]. More research is needed on microbial ecology and population development in aerobically deteriorating silage, in order to clearly define the conditions which predispose silages to spoilage of this type. In the interim, emphasis is perceptibly shifting towards the inclusion of micro-organisms that produce antimicrobial products in silage additives [43]. Although other approaches are being made, it is intended to concentrate on the antimycotic effects of propionic acid and the potential of the propionibacteria as a biotechnological vehicle for delivering propionic acid in the silo. The choice of these organisms, 
which are not generally part of the average silage microflora, will first be put into context in relation to experience with the direct application of propionic acid to forage.

\section{PROPIONIC ACID} AS AN ANTIMYCOTIC AGENT

Organic acids, in particular formic acid, have been widely used as silage additives since the 1950's [78]. The beneficial effects of longer chain acids in inhibiting microbial activity during the storage of crops has been recognized for a number of years [30]. Woolford [76] screened the straight chain fatty acids from formic to lauric acids $\left(\mathrm{C}_{1}-\mathrm{C}_{12}\right)$ as potential silage additives and concluded that there was a decrease in the minimum inhibitory concentration of these acids required to inhibit the growth of a range of silage micro-organisms, including yeasts and moulds, with increasing chain length. More recently, Davies et al. $[10,11]$ concluded that a number of LAB inoculants were considerably less effective at reducing aerobic spoilage in maize silage than an additive containing mainly formic acid and low concentrations of longer chain volatile fatty acids. Research has shown that a propionic acid concentration of $1.5-6 \mathrm{~g} \cdot \mathrm{L}^{-1}$ in laboratory broth culture was inhibitory to yeasts and indicated that concentrations of between 10 and $30 \mathrm{~g} \cdot \mathrm{kg}^{-1} \mathrm{DM}$ in silage would inhibit aerobic deterioration, if added at the onset of ensilage $[5,24]$. Subsequently, Woolford and Cook [82] observed that in low DM maize silage which had been treated with propionic acid $\left(12.5 \mathrm{~g} \cdot \mathrm{kg}^{-1} \mathrm{DM}\right)$ aerobic spoilage was reduced, and in high DM maize silage at the same application rate, deterioration was completely inhibited. In other laboratory experiments, Moon [44] showed that propionic acid was more inhibitory to acid tolerant yeasts than acetic or lactic acids and that the synergistic effect of mixtures of the two acids had even greater inhibitory activity. Driehuis et al. [18] examined the effects of adding propionic, acetic or formic acids to grass silage. Propionic acid was the most effective at lowering yeast counts, with 100 and 1000 -fold lower counts after $6 \mathrm{~d}$ of ensiling than acetic and formic acids, respectively. Unlike formic acid, it had the advantage of not retarding LAB growth over the important initial phases of the fermentation, resulting in better quality silage. There has been increasing interest in the use of propionate additives for preservation of high DM forages $[17,57]$ and also whole grains $[56,64]$. Propionic acid has been shown to have other beneficial effects during ensilage, including reducing ammonia- $\mathrm{N}$ concentration, reducing temperature, stimulating the growth of lactic acid bacteria and improving DM intake [40]. The move towards biological as opposed to chemical silage additives has stimulated interest in coupling fermentation control by lactic acid bacteria with propionibacteria, to express propionic acid in the silo, to tackle the aerobic spoilage problem. In the UK, over 60 biological additives containing LAB are marketed commercially and $8 \%$ of these also include strains of Propionibacteria species [3].

\section{PROPIONIC ACID PRODUCING BACTERIA AND THEIR ROLE IN SILAGE}

The term propionic acid producing bacteria has been used in some earlier published articles where it is not always clear whether the organisms being referred to were members of the genus Propionibacteria or whether they were other organisms that produce propionic acid as a major end-product. To our knowledge, there are fewer than 20 published reports on propionic acid producing bacteria and their activities in silage and Dawson et al. [13] have previously concluded that the "published research concerning the use of propionic acid producing bacteria as silage inoculants is lacking and practically devoid". This situation has only improved slightly in the last 5 years. Publications range 
from the isolation of propionic acid producing bacteria from silage $[14,16,75]$ to their inclusion in silage inoculants (table I) and one publication concerned itself with mathematical modeling approaches to assess their potential during ensilage [55].

\subsection{Isolation from herbages and silages}

The natural occurrence of propionic acid producing bacteria in silage has only been reported on a limited number of occasions. Propionic acid can be formed in silage by several micro-organisms other than propionibacteria, including Micrococcus lactilyticus, Lactobacillus bifermentans and Clostridium propionicum [16]. However, de Man [16] isolated $P$. freudenreichii and unconfirmed isolates of $P$. zeae from potato pulp silage and grass/potato pulp silage mixtures. In later studies, Woolford [75] was unsuccessful in isolating propionic acid producing bacteria from 8 different forages including ryegrass, red clover, lucerne and maize, but micro-organisms resembling Propionibacteria sp. were isolated from 2 out of the 8 resulting silages. More recently, Dawson et al. [14] used an enrichment culture procedure and only isolated one presumptive Propionibacterium sp. from a total of 38 ensiled feeds (including alfalfa haylage, oatlage, corn and high moisture corn silage). The organism was shown to ferment glucose (to produce the proportions of 1 acetate to 3 propionate) and lactate (to produce the proportions of 1 acetate to 5 propionate) and to grow rapidly under anaerobic conditions using glucose as a substrate and this showed potential as a silage inoculant organism [14]. In our own studies (Bakewell E.L., Davies D.R. and Merry R.J., unpublished results), we failed to isolate propionibacteria from in excess of 20 grass silages, 2 maize silages, and 4 whole crop silages, despite using a range of media (including the yeast extract sodium lactate agar of Hettinga et al. [26], the trypticase lactate agar of Peberdy and
Fryer [52], a synthetic medium described by Woolford [75], the sodium lactate agar of Drinan and Cogan [19] and the ammonium sulphate lactate agar of Peberdy and Fryer [52]). The main problem in our studies was that the media did not suppress the growth of the lactic acid bacteria that predominate during the ensilage process, and attempts to adapt the media were unsuccessful. The difficulty of isolating propionibacteria from silage, even when it has been applied as an inoculant has been endorsed by findings of other silage researchers (personal communication Dr K. Bolsen; $[67,58])$, and is due to one of two possibilities. Either propionibacteria are generally unable to survive conditions during ensilage and are thus not recovered, or the media used for their isolation are not sufficiently selective to inhibit the growth of lactic acid bacteria.

\subsection{Inoculation prior to ensilage}

A summary of the experimental conditions and findings where propionibacteria or propionic acid producing bacteria were used as components of silage inoculants is shown in table $I$.

The first report of propionic acid producing bacteria being used to inoculate plant material prior to storage was by Lindgren et al. [36] and it was followed by a limited number of other reports in the succeeding years (table I). In these studies, the crops to be ensiled included wilted grass, pearl millet, wheat, sorghum, maize and orange pulp and the organisms used ranged from unspecified propionic acid producing bacteria, to culture collection strains of $P$. freudenreichii, $P$. acidipropionici and $P$. shermanii. Wyss et al. [86] demonstrated an increase in the aerobic stability of silage prepared with an inoculum of both LAB and propionic acid producing bacteria, but in this study, silo sealing was delayed in order to slow the rate of $\mathrm{pH}$ decline and to give the propionic acid producing bacteria a greater chance of establishment. In support of these 
Table I. Published research on use of propionic acid producing bacteria as silage inoculants.

Tableau I. Travaux de recherche publiés sur l'utilisation de bactéries productrices d'acide propionique pour ensemencer l'ensilage.

\begin{tabular}{|c|c|c|c|}
\hline Crop & Inoculant & Result & Source \\
\hline Grass & P. shermanii & No propionic acid production. & [36] \\
\hline High moisture corn & P. shermanii & Lower yeast counts than untreated. & [22] \\
\hline Wilted grass & Propionibacteria spp. & $\begin{array}{l}\text { Improved aerobic stability, but delayed silo sealing was practiced } \\
\text { to slow the initial fermentation. }\end{array}$ & [86] \\
\hline Reconstituted corn & $\begin{array}{l}\text { P. acidipropionici (ATCC 4965) + } \\
\text { P. freudenreichii (ATCC 6207) }\end{array}$ & Increased propionic acid and decreased yeast and mould counts. & [12] \\
\hline Orange pulp & Propionic acid producing bacterium & $\begin{array}{l}\text { Increased propionate over control but all silages were aerobically } \\
\text { stable. Limited evidence for improved fermentation. }\end{array}$ & [2] \\
\hline Wilted grass & Propionibacteria spp. & $\begin{array}{l}\text { Increased stability over the control but not compared to lactic acid } \\
\text { bacteria treated silages (Air stress slowed lactic acid production } \\
\text { and increased propionic acid concentration). }\end{array}$ & [49] \\
\hline Wilted grass & Propionibacteria spp. & $\begin{array}{l}\text { Increased aerobic stability (Air stress slowed lactic acid production } \\
\text { and increased propionic acid concentration). }\end{array}$ & [87] \\
\hline $\begin{array}{l}\text { Pearl millet and whole } \\
\text { crop maize }\end{array}$ & P. shermanii & $\begin{array}{l}\text { Marginal effect on aerobic stability. } \\
\text { Propionibacteria not detected after ensilage. }\end{array}$ & [67] \\
\hline Wheat and sorghum & P. shermanii & $\begin{array}{l}\text { Improved stability in } 1 \text { out of } 5 \text { experiments, probably due } \\
\text { to a slow initial silage fermentation in the experiment where } \\
\text { improvement was observed. }\end{array}$ & [68] \\
\hline Whole crop maize & $\begin{array}{l}\text { P. shermanii applied at either } \\
10^{5} \text { or } 10^{6} \mathrm{CFU} \cdot \mathrm{g}^{-1} \mathrm{FM}\end{array}$ & $\begin{array}{l}\text { Propionic acid produced and substantially increased } \\
\text { aerobic stability. }\end{array}$ & [7] \\
\hline Grass & $\begin{array}{l}\text { P. freudenreichii subsp. shermanii } \\
+ \text { Lactobacillus rhamnosus }\end{array}$ & $\begin{array}{l}\text { Neither propionic acid or Propionibacteria were detected } \\
\text { in the silages. }\end{array}$ & [58] \\
\hline
\end{tabular}

Improved stability in 1 out of 5 experiments, probably due to a slow initial silage fermentation in the experiment where .

Propionic acid produced and substantially increased 
findings, whole crop wheat which had been inoculated with $P$. shermanit fermented slowly and the silage had a propionic acid concentration of $19.5 \mathrm{~g} \cdot \mathrm{kg}^{-1}$ DM, coupled with increased aerobic stability, in comparison with untreated silages [68]. However, in the same study, with both whole crop wheat and sorghum, and where fermentation was more rapid, little or no propionic acid was detected and no improvement in aerobic spoilage was observed. Other researchers $[2,49,67]$ have also found little or no evidence for an increase in aerobic stability after inoculation of forage with propionic acid producing bacteria, unless silo sealing is delayed. This led Weinberg et al. [68] to conclude that inoculation with propionibacteria had only marginal effects on the aerobic stability of silages, which is probably due to their inability to grow in good ensiling conditions, where a rapid initial fermentation and lowering of $\mathrm{pH}$ has occurred. These conclusions are supported by Pitt [55] using a mathematical modeling approach. He predicted that inoculation with propionic acid bacteria would have the smallest potential benefit in those silages that are most prone to aerobic deterioration, i.e. those that are well fermented, presumably due to the initial rapid $\mathrm{pH}$ decline, and have high concentrations of lactic acid and residual fermentable substrate.

On the other hand, inoculation of either high moisture ( $27 \%$ moisture content) or reconstituted corn with propionibacteria before fermentation, can result in reduced yeast and mould counts and increased concentrations of propionic acid [12, 22], implying that upon exposure of these silages to air, there would be reduced losses due to fungal activity. In a more recent study, where Bolsen [7] examined the effect of inoculating whole crop maize with $P$. shermanii $\left(10^{5}\right.$ or $10^{6} \mathrm{CFU} \cdot \mathrm{g}^{-1}$ fresh crop) with or without $\mathrm{LAB}$, results were also encouraging. Despite the rapid fermentation in all silages, those inoculated with $P$. shermanii had detectable amounts of propionic acid ( 0.8 to $2.2 \mathrm{~g} \cdot \mathrm{kg}^{-1} \mathrm{DM}$ ), the highest concen- tration being recorded in the silage where $P$. shermanii alone was included at the highest inoculation level. The $P$. shermanii inoculated silages, with or without addition of $\mathrm{LAB}$, were very stable upon exposure to air compared to untreated control and LABonly inoculated silages. There was no detectable first temperature peak, and the initial temperature rise was delayed by $48 \mathrm{~h}$ in the silage inoculated with the highest levels of $P$. shermanii alone. In studies carried out in our laboratory (Bakewell E.L., Davies D.R., Merry R.J., unpublished results), 14 culture collection strains of propionibacteria, including strains of the species $P$. freudenreichii, $P$. freudenreichii sbsp. shermanii and $P$. jensenii were screened for propionic acid production in Woolford and Wilkins' [83] good ensiling potential medium. Two strains ( $P$. freudenreichii sbsp. shermanii [NCIMB 8099 ] and $P$. jensenii [NCIMB 5960]) produced concentrations (ca. $9 \mathrm{~g} \cdot \mathrm{L}^{-1}$ ) that would, according to Woolford [78], be adequate to prevent the growth of fungi. The above two strains in a mixture were used to inoculate whole crop maize at a rate of $5 \times 10^{5} \mathrm{CFU} \cdot \mathrm{g}^{-1}$ FM of each and the resultant silages were assessed for their aerobic stability, compared to corresponding untreated and LAB inoculated silages. An increase in aerobic stability as indicated by a reduction in the time taken for the temperature to reach $25^{\circ} \mathrm{C}$ was observed in the propionibacteria inoculated silages, compared to either untreated or LAB inoculated silages (table $I I$ ). However, a concentration of only $0.6 \mathrm{~g} \cdot \mathrm{kg}^{-1}$ DM was detected in the propionibacteria treated silages, which is well below the minimum inhibitory concentration for yeasts and moulds suggested by Woolford [78]. It is well documented that propionibacteria produce bacteriocins or other anti-microbial products $[23,38,51]$, and there is a possibility that one of these products rather than propionic acid per se caused the increase in aerobic stability in this study, due to the inhibition of either yeasts, moulds or acetic acid bacteria. 
Table II. Concentrations of volatile fatty acids, lactic acid and $\mathrm{pH}$ values in $90 \mathrm{~d}$ maize silages, and the time taken for the silage temperature to reach $25^{\circ} \mathrm{C}$ after exposure to air.

Tableau II. Concentrations en acides gras volatils et acide lactique, en valeur de $\mathrm{pH}$ dans un ensilage maïs de $90 \mathrm{j}$, et en temps mis par l'ensilage après ouverture à l'air pour atteindre $25^{\circ} \mathrm{C}$.

\begin{tabular}{lccccc}
\hline Treatment & $\mathrm{pH}$ & $\begin{array}{c}\text { Acetate } \\
\left(\mathrm{g} \cdot \mathrm{kg}^{-1} \mathrm{DM}\right)\end{array}$ & $\begin{array}{c}\text { Propionate } \\
\left(\mathrm{g} \cdot \mathrm{kg}^{-1} \mathrm{DM}\right)\end{array}$ & $\begin{array}{c}\text { Lactate } \\
\left(\mathrm{g} \cdot \mathrm{kg}^{-1} \mathrm{DM}\right)\end{array}$ & $\begin{array}{c}\mathrm{Time}^{1}(\mathrm{~h}) \text { to } \\
\text { reach } 25^{\circ} \mathrm{C}\end{array}$ \\
\hline Untreated & 3.49 & 27.46 & $\mathrm{ND}$ & 57.41 & $61(18)$ \\
LAB & 3.52 & 28.86 & $\mathrm{ND}$ & 56.95 & $54(10.9)$ \\
LAB + P & 3.71 & 32.06 & $0.56^{2}$ & 43.75 & $65(11.3)$
\end{tabular}

$\mathrm{ND}=$ not detected.

$\mathrm{LAB}=$ Lactobacillus plantarum applied at $10^{6} \mathrm{CFU}, \mathrm{g}^{-1} \mathrm{FM}$.

$P=P$. freudenreichii subsp. shermanii and $P$. jensenii applied to give a total propionibacterium inoculation rate of $10^{6} \mathrm{CFU} \cdot \mathrm{g}^{-1} \mathrm{FM} .{ }^{1}$ Values in parentheses denote the percentage coefficient of variation between replicates. All values are the mean of 3 replicate silages.

$\mathrm{ND}=$ non détecté.

$\mathrm{LAB}=$ Lactobacillus plantarum inoculé à $10^{6} \mathrm{ufc} \cdot \mathrm{g}^{-1}$ de matière frâiche.

$P=P$. freudenreichii subsp. shermanii et $P$. jenserii inoculés pour atteindre un total en bactéries propioniques de $10^{6}$ ufc $\cdot \mathrm{g}^{-1}$ de matière fraiche. 'Valeurs entre parenthèses donnent les coefficients de variations (\%) entre les répétitions. Toutes les valeurs sont la moyenne de 3 ensilages.

\section{CO-CULTURE OF PROPIONIBACTERIA AND LACTIC ACID BACTERIA}

A problem often encountered with the use of propionibacteria as silage inoculants is their apparent inability to grow and survive in rapidly fermenting silage where lactic acid bacteria played a major role and where $\mathrm{pH}$ declined rapidly $[67,68,86]$. There are a number of publications where the growth and interrelationships between co-cultures of Lactobacillus sp. and Propionibacteria sp. under laboratory conditions have been reported $[6,37,50,53,54]$. Results from these studies demonstrate the complexity of the interrelationships between bacteria from these two genera, with findings ranging from inhibition of both organisms, to inhibition of the propionibacterium or to the enhanced growth of both organisms. In the most extensive study, 4 organisms from each genus were co-cultured in all possible permutations ( 16 in total), and culture density, $\mathrm{CO}_{2}$ and acidic end-products were determined after $12 \mathrm{~d}$ incubations [50]. Fifteen of the co-cultures produced less end- products and had lower culture densities than their pure culture counterparts. The Propionibacterium sp. was most commonly inhibited, but in one study with $L$. acidophilus and $P$. shermanii growth and endproduct formation was enhanced. These experiments clearly demonstrated the complexities involved in the co-culturing of these two genera of micro-organisms. In general, where the $\mathrm{pH}$ of the co-culture is allowed to fall, as would be the case in the silo, inhibition of the Propionibacterium sp. occurs [54].

The above reports all relate to the bacteria used in the cheese industry, but in 2 studies, the growth of propionibacteria in combination with typical silage bacteria have been examined $[36,75]$. Woolford [75] used a simulated silage model system to investigate the potential of one strain each of $P$. freudenreichii and $P$. jensenii as silage inoculants in various combinations with one or more of the following organisms: L. plantarum, Enterococcus faecalis, Leuconostoc mesenteroides and Clostridia spp. The simulated silage was inoculated with propioni- 
bacteria at $10^{3} \mathrm{CFU} \cdot \mathrm{g}^{-1} \mathrm{FM}$ and, under these conditions, could be enumerated during the entire $64 \mathrm{~d}$ period in the simulated silage, with numbers in excess of $2 \times 10^{6}$

$\mathrm{CFU} \cdot \mathrm{g}^{-1} \mathrm{FM}$ by the end of the experiment. It was concluded that propionibacteria could survive the ensilage process even when $\mathrm{pH}$ dropped to below 4 . Lindgren et al. [36] used brain-heart infusion glucose medium to culture $P$. shermanii with either L. plantarum or Pediococcus acidilactici and examined the kinetics of acetic, lactic and propionic acid production over a period of $12 \mathrm{~d}$ (figure 3). An initial accumulation of lactic acid occurred when $P$. shermanii was co-cultured with $L$. plantarum, which was subsequently used for acetic and propionic acid production. In the co-culture with $P$. acidilactici, lactic acid was immediately utilized for acetic and propionic acid production and did not accumulate. Clearly, the benefits of propionic acid production must be offset against the use of lactic acid as a substrate, although a natural cut-off would occur as $\mathrm{pH}$ declined and propionibacteria were inhibited.

\section{CONCLUSIONS ON THE POTENTIAL OF PROPIONIBACTERIA AS SILAGE INOCULANTS}

In 1995, Weinberg et al. [67] observed that "although the production of propionic acid during the fermentation phase is a sound concept, results in a limited number of controlled experiments have been inconsis-
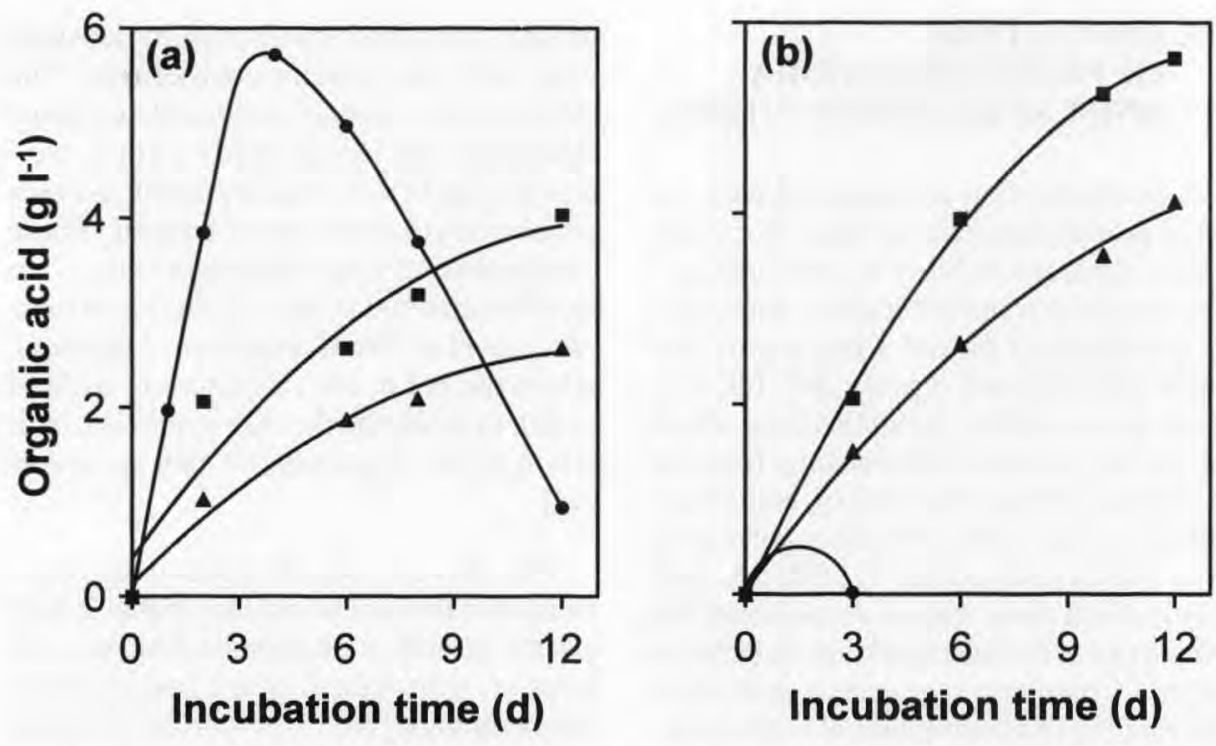

Figure 3. Changes in lactic acid (-), propionic acid ( $\mathbf{\square})$ and acetic acid ( $\mathbf{\Delta})$ concentrations during the co-culture of Propionibacterium shermanii with (a) Lactobacillus plantarum and (b) Pediococcus acidilactici. Cultures where grown in flasks containing brain-heart infusion plus glucose medium [36].

Figure 3. Évolution des concentrations en acide lactique (-), acide propionique (- et acide acétique (A) au cours de la culture mixte de Propionibacterium shermanii associé à Lactobacillus plantarum (a) et Pediococcus acidilactici (b). Les cultures étaient réalisées en flacons contenant un bouillon cœurcervelle et un milieu glucose [36]. 
tent". Indeed, a concerted effort is required to overcome the inconsistencies as there are other possible benefits than solely increased aerobic stability of silage. Propionibacteria have the potential to increase the health and nutritional status of the ruminant and this has already received limited attention (Kung et al., 1992 cited in [13]). Propionibacteria have been used for vitamin $B_{12}$ and proline production $[8,34]$. If produced during ensilage, these compounds may stimulate rumen microbial activity in silage-fed animals, with possible health and nutritional benefits. There are some early reports of propionibacteria being isolated from the rumen ecosystem [20]. If the inoculated propionibacteria remained viable after ensilage and were metabolically active in the rumen, they could convert lactic acid to propionate and play a role in reducing the incidence of lactic acidosis in ruminants. Increased molar proportions of propionate have been shown to raise protein: fat ratios in meat and dairy products [1]. Thus, there are several potential benefits to be gained by the use of propionibacteria as silage inoculant organisms and future research needs to be targeted at improving their efficacy. Current problems in methodology need to be addressed in order to find an ideal organism adapted to the silage ecosystem for use as a silage inoculant. When seeking a suitable LAB strain for a silage inoculant, Wieringa [72] isolated 81 strains, but only one had the characteristics required. It is doubtful whether this number of propionibacteria have ever been isolated from silages and examined for their potential as silage inoculants. It is thus of paramount importance that screening procedures are improved to enable selections of bacteria with suitable characteristics. Whittenbury [71] defined the criteria that LAB should satisfy for use as silage inoculants, and some of these could usefully be adapted for selecting the new and more competitive propionibacteria for use as silage inoculants. viz, they should:

- Multiply rapidly using both forage carbohydrates and minimal amounts of lactic acid as substrates, to produce the maximum concentrations of propionic acid during the early stages of the fermentation.

- Tolerate $\mathrm{pH}$ values as low as 4-4.5.

- Have the potential to produce antimicrobial products to inhibit the growth of yeasts, moulds and if possible acetic acid bacteria.

Moreover, the use of a pre-culturing system to provide actively dividing rather than freeze-dried bacteria as inoculants may enhance the activity of propionibacteria during the initial stages of ensilage. This approach has already been exploited by Merry et al. [42] for on-farm culture of $L$ plantarum for inoculating grass and cereal silages.

These approaches rely on the improvement of selective media for the culture of naturally occurring propionibacteria to provide a wider range of herbage and silage isolates for subsequent screening. Success with these objectives may lead to a more robust system with organisms, better adapted to ensilage conditions and provide a new generation of propionibacteria-containing inoculants to address the problem of aerobic instability of silage.

\section{REFERENCES}

[1] Abzul-Razzaq H.A., Bickerstaffe R., The influence of rumen volatile fatty acids on protein metabolism in growing lambs, Bromatol. J. Nutr. 62 (1989) 297-310.

[2] Alio V.B., Oleas T.B., Dawson T.E., Ullrey D.E., Cook R.M., Effect of sorghum grain and propionic acid bacteria on fermentation pattern, dry matter loss and aerobic stability of orange pulp silage, J. Agr. Food Chem. 42 (1994) 762-765.

[3] Anon, Forage Additives Supplement, Farmers Weekly $21^{\text {st }}$ November 1997.

[4] Barry T.N., di Menna M.E., Webb P.R., Parle J.N., Some observations on aerobic deterioration in untreated silages and in silages made with formaldehyde-containing additives, J. Sci. Food Agr. 31 (1980) 133-146.

[5] Beck T., The effect of ensiling agents on aerobic deterioration, Das Wirtschaftseigene Futter 21 (1975) 55-65. 
[6] Bodie E.A., Goodman N., Schwartz R.D., Production of propionic acid by mixed cultures of Propionibacterium shermanii and LactobacilIus casei in autoclave-sterilized whey, J. Ind. Microbiol. 1 (1987) 349-353.

[7] Bolsen K.K., Bonilla D.R., Huck G.L., Young M.A., Hart-Thakur R.A., Effect of propionic acid bacterial inoculant on fermentation and aerobic stability of wholecrop maize silage, in: Jones D.I.H., Jones R., Dewhurst R., Merry R.J., Haigh P.M. (Eds.), Proc. 11 th Int. Silage Conf., Univ. Wales, Aberystwyth, UK, 1996, pp. 154-155.

[8] Bullerman L.B., Berry E.E., Use of cheese whey for vitamin $B_{12}$ production, Appl. Microbiol. 14 (1966) 353-355.

[9] Chamberlain D.G., Quig J., The effects of rate of addition of formic acid and sulphuric acid on the ensilage of perennial ryegrass in laboratory silos, J. Sci. Food Agr. 38 (1987) 217-228.

[10] Davies D.R., Merry R.J., Bakewell E.L., The effect of timing of slurry application on the microflora of grass, and changes occurring during silage fermentation, Grass Forage Sci. 51 (1996) 42-51.

[11] Davies D.R., Merry R.J., Jones R., Fychan R., Effect of different additives on the aerobic stability of ensiled wholecrop maize, in: Jones D.I.H., Jones R., Dewhurst R., Merry R.J., Haigh P.M. (Eds.). Proc. 11th Int, Silage Conf., Univ. Wales, Aberystwyth, UK, 1996, pp. 264-265.

[12] Dawson T.E., Miranda L.A., Yokoyama M.T., Rust S.R., Inoculation of reconstituted high moisture corn with propionic acid producing bacteria with or without addition of lactic acid bacteria, 21st Biennial Conference on Rumen Function, Chicago Illinios, 1991. Abstract 62.

[13] Dawson T.E., Rust S.R., Yohoyama M.T., Manipulation of silage fermentation and aerobic stability by propionic acid producing bacteria, in: Silage Production from Feed to Animal, NRAES-67, Northeast Regional Agricultural Engineering Service, Syracuse, New York State, USA, 1993, pp. 96-105.

[14] Dawson T.E., Yokoyama M.T., Rust S.R., Enrichment, isolation, and characterisation of propionic acid producing bacteria from ensiled feedstuffs, J. Anim. Sci. 70 (1992) 86

[15] Day C.A., Liscansky S.G., Agricultural alternatives, in: Forster C.F., Wase D.A.J. (Eds.), Environmental Biotechnology, Ellis Horwood Ltd,. Chichester, 1987, pp. 234-294.

[16] de Man J.C., Some observations on propionic acid fermentation in silage, Antonie Van Leeuwenhoek 23 (1957) 81-86.

[17] Driehuis F., Van Wikselaar P.G., Effects of addition of formic, acetic or propionic acid to maize silage and low dry matter grass silage on the microbial flora and aerobic stability, in: Jones D.I.H., Jones R., Dewhurst R., Merry R.J., Haigh P.M. (Eds.), Proc. 11th Int. Silage Conf., Univ. Wales, Aberystwyth, UK, 1996, pp. 107-107.
[18] Driehuis F., Van Wikselaar P.G., Van Vuuren A.M., Effect of fromic, acetic and propionic acid on preservation and aerobic deterioration of grass silage, Ann. Zootech. 44 suppl (1995) 95.

[19] Drinan F.D., Cogan T.M., Detection of propionic acid bacteria in cheese, J. Dairy Res. 59 (1992) 65-69.

[20] Elsden S.R., Fermentation of carbohydrates in the rumen of sheep, J. Exp. Biol. 22 (1945) 51-62.

[21] Fenlon D.R., Wilson J., Weddell J.R., The relationship between spoilage and Listeria monocytogenes contamination in bagged and wrapped big bale silages, Grass Forage Sci. 44 (1989) 97-100.

[22] Flores-Galarza R.A., Glatz B.A., Bern C.J., Van Fossen L.D., Preservation of high-moisture corn by microbial fermentation, J. Food Prot. 48 (1985) 407-411.

[23] Grinstead D.A., Barefoot S.F., Jenseniin G, a heat-stable bacteriocin produced by Propionibacterium jensenii P126, Appl. Env. Microbiol. 58 (1992) 215-220.

[24] Gross F., Beck T., Investigations into the prevention of aerobic degradation processes after unloading of silage with propionic acid, Das Wirtschaftseigene Futter 16 (1970) 1-14.

[25] Henderson A.R., McDonald P., Woolford M.K., Chemical changes during the ensilage of wilted grass treated with formic acid, J. Sci. Food Agr. 23 (1972) 1079-1087.

[26] Hettinga D.H., Vedamuthu E.R., Reinhold G.W., Pouch method for isolating and enumerating propionibacteria, J. Dairy Sci. 51 (1968) 1707-1709.

[27] Holden A.N.G lants on acrobic stability, Ph.D, thesis, University of Newcastle upon Tyne, UK, 1987.

[28] Honig H.H., Schild J.G., Daenicke R., Wirkung eines Impfzusatzes in Maissilage-Garverlauf, Verluste und Aerobe Stabilitat, VDLUFA Congress, Gottingen, Germany, 1992, pp. 399-402.

[29] Honig H., Woolford M.K., Changes in silage on exposure to air, in: Thomas C. (Ed.), Forage Conservation in the 80 's, Occasional Symposium No. 11 of the British Grassland Society, Hurley, Maidenhead, UK, 1980, pp. 77-87.

[30] Jones G.M., Mowat D.N., Elliot J.I., Moran E.T., Organic acid preservation of high moisture corn and other grains and the nutritional value: a review, Can. J. Anim. Sci. 54 (1974) 499-517.

[31] Jonsson A., Lindberg H., Sundas S., Lingvall P., Lindgren S., Effect of additives on the quality of big bale silages, Anim. Feed Sci. Technol. 31 (1990) 139-155.

[32] Jonsson A, Pahlow G., Systematic classification and biochemical characterization of yeasts growing in grass silage inoculated with lactobacillus cultures, Anim. Res. Dev. 20 (1984) $7-22$. 
[33] Kennedy S.J., Evaluation of three bacterial inoculants and formic acid as additives for first harvest grass, Grass Forage Sci. 45 (1990) 281-288.

[34] Langsrud T., Reinhold G.W., Hammond E.G., Free proline production by strains of propionibacteria, J. Dairy Sci. 61 (1978) 303-308.

[35] Lindgren S.E., Dobrogorsz W.J., Antagonistic activities of lactic acid bacteria in food and feed fermentations, FEMS Microbiol. Rev. 87 (1990) 149-164.

[36] Lindgren S., Lingval P., Kaspersson A., Kartzow A., Rydberg E., Effect of inoculants, grain and formic acid on silage fermentation, Swedish J. Agr. Res. 13 (1983) 91-100.

[37] Liu J.A.P., Moon N.J., Commensalistic interaction between Lactobacillus acidophilus and Propionibacterium shermanii, Appl. Env. Microbiol. 44 (1982) 715-722.

[38] Lyon W.J., Glatz B.A., Partial purification and characterization of a bacteriocin produced by Propionibacterium theonii, Appl. Env. Microbiol. 57 (1991) 701-706.

[39] Mason V.C., Merry R.J., Braithwaite G.D., Cook J.E., Jones L., Hoadley C.J., Preservation of whole crop wheat using acid and alkaline additives, in: Proc. Eighth Silage Conf., Hurley, Maidenhead, Berks., UK, 1987, pp. 191-192.

[40] McDonald P., Henderson A.R., Heron S.J.E., The Biochemistry of Silage, Chalcombe Publications, Marlow, UK, 1991, pp. 340.

[41] Merry R.J., Cussen-Mackenna R.F., Jones R.F., Biological silage additives, Ciencia e Investigacione Agraria 20 (1993) 372-401.

[42] Merry R.J., Dhanoa M.S., Theodorou M.K., Use of freshly cultured lactic acid bacteria as silage inoculants, Grass Forage Sci. 50 (1995) $112-123$.

[43] Merry R.J., Lowes K.F., Winters A.L., Current and future approaches to biocontrol in silage, in: Jambor V., Klapil L., Chromec P., Prochazka P. (Eds.), Proc. 8th Int. Symp. Forage Conservation, Research Institute of Animal Nutrition, Pohorelice, Czech Republic, 1997, pp. 17-27.

[44] Moon N.J., Inhibition of the growth of acid tolerant yeasts by acetate, lactate and propionate and their synergistic mixtures, J. Appl. Bacteriol. 55 (1983) 453-460.

[45] Moon N.J., Ely L.O., Identification and properties associated with the aerobic deterioration of wheat and alfalfa silages, Mycopathologia 69 (1979) $153-156$.

[46] Middelhoven W.J., Franzen M.M., The yeast flora of ensiled whole-crop maize, J, Sci. Food Agr. 37 (1986) 855-861.

[47] Ohyama Y., Hara S., Masaki S., The use of caproic acid to prevent aerobic deterioration of silages after opening with special reference to the amounts and time of application, J. Sci. Food Agr. 28 (1977) 369-374.
[48] Oldenburg E., Mycotoxins in conserved forage, Landbauforsch. Volkenrode 123 (1991) 191-205.

[49] Pahlow G., Honig H., The role of microbial additives in the aerobic stability of silage, in: Workshop Proc. $15^{\text {th }}$ General Meeting of the European Grassland Federation, Netherlands Society for Grassland and Fodder Crops, Wageningen, the Netherlands, 1994, pp. 149-151.

[50] Parker J.A.P., Moon N.J., Interactions of Lac tobacillus and Propionibacterium in mixed culture, J. Food Prot. 45 (1982) 326-330.

[51] Paul G.E., Booth S.J., Properties and characteristics of a bacteriocin-like substance produced by Propionibacterium acnes, Can. J. Microbiol. 34 (1988) 1344-1347.

[52] Peberdy M.F., Fryer T.F., Improved selective media for the enumeration of Propionibacteria from cheese, NZJ Dairy Sci. Technol. 11 (1976) 10-15.

[53] Perez-Chaia A., Pesce De Ruiz Holgado A., Oliver G., Interaction between Lactobacillus helveticus and Propionibacterium freudenreichii subsp. shermanii, Microbiol. Aliments Nutr. 5 (1987) 325-331.

[54] Perez-Chaia A., Strasser De Saad A.M., Pesce De Ruiz Holgado A., Oliver G., Competitive inhibition of Propionibacterium acidipropionici by mixed culturing with Lactobacillus helveticus, J. Food Prot. 56 (1994) 341-344.

[55] Pitt R.E., Modeling the effects of propionic acid bacteria in silage, Trans. Amer. Soc. Agr. Eng. 40 (1997) 405-4II.

[56] Raeker M.O., Bern C.J., Johnson L.A., Glatz B.A., Preservation of high-moisture maize by various propionate treatments, Cereal Chem. 69 (1992) 66-69.

[57] Randby A.T., Moulding and aerobic stability of round-bale grass silage treated with formic or propionic acid, in: Jones D.I.H., Jones R., Dewhurst R., Merry R.J., Haigh P.M. (Eds.), Proc. 11 th Int. Silage Conf., Univ. Wales, Aberystwyth, UK, 1996, pp.107-107.

[58] Rauramaa A., Tommila A., Nousianen J., Toivonen V.. The effect of Lactobacillus rhamnosus and Propionibacterium freudenreichii ssp. shermanii on chemical and microbial composition of prewilted silages, in: Jones D.I.H., Jones R., Dewhurst R., Merry R.J., Haigh P.M. (Eds.), Proc. 11th Int. Silage Conf, Univ. Wales, Aberystwyth, UK, 1996, pp.107-107.

[59] Rooke J.A., The numbers of epiphytic bacteria on grass at ensilage on commercial farms, J. Sci. Food Agr. 51 (1990) 525-533.

[60] Ruxton I.B., McDonald P., The influence of oxygen on ensilage, J. Sci. Food Agr. 25 (1975) 107-115.

[61] Sanderson M.A., Aerobic stability and in vitro fiber digestibility of microbially inoculated corn and sorghum silages, J. Anim. Sci. 71 (1993) $505-514$. 
[62] Seale D.R., Bacterial inoculants as silage additives, J. Appl. Bacteriol. (Symp. Suppl.) (1986) 9S-26S.

[63] Seale D.R., Henderson A.R., Petterson K.O., Lowe J.F., The effect of addition of sugar and inoculation with two commercial inoculants on the fermentation of lucerne silage in laboratory silos, Grass Forage Sci. 41 (1986) 62-70.

[64] Sebastian S., Phillip L.E., Fellner V., Idziak E.S., Comparative assessment of bacterial inoculation and propionic acid treatment on aerobic stability and microbial populations of ensiled high-moisture ear corn, J. Anim. Sci. 74 (1996) $447-456$.

[65] Spoelstra S.F., Degradation of nitrate by enterobacteria during silage fermentation of grass, Neth. J. Agr. Sci. 35 (1987) 43-54.

[66] Spoelstra S.F., Courtin M.G., van Beers J.A.C., Acetic acid bacteria can initiate aerobic deterioration of maize silage, J. Agr. Sci. 111 (1988) 127-132.

[67] Weinberg Z.G., Ashbell G., Bolsen K.K., Pahlow G., Hen Y., Azrieli A., The effect of a propionic acid bacterial inoculant applied at ensiling, with or without lactic acid bacteria, on the aerobic stability of pearl-millet and maize silages, J. Appl. Bacteriol. 78 (1995) 430-436.

[68] Weinberg Z.G., Ashbell G., Hen Y., Azerieli A., The effect of a propionic acid bacterial inoculant applied at ensiling on the aerobic stability of wheat and sorghum silages, J. Ind. Microbiol. 15 (1995) 493-497.

[69] Weinberg Z.G., Ashbell G., Hen Y., Azerieli A., The effect of applying lactic acid bacteria at ensiling on the aerobic stability of silage, J. Appl. Bacteriol. 75 (1993) 512-518.

[70] Weinberg Z.G., Muck R.E., New trends and opportunities in the development and use of inoculants for silage, FEMS Microbiol. Rev. 19 (1996) 53-68.

[71] Whittenbury R., An investigation of the lactic acid bacteria, $\mathrm{Ph} . \mathrm{D}$. thesis, University of Edinburgh, UK, 1961.

[72] Wieringa G.W., The influence of green forages on fermentation, Futterkonservierung 7 (1961) $27-35$.

173] Wilkinson J.M., Wadephul F., Hill J., Silage in Europe - A Survey of 33 Countries, Chalcombe Publications, Lincoln, UK, 1996.

[74] Williams A.G., Critten D.L., Reynolds A.M., A mathematical model of the aerobic deterioration of silage, Grass Forage Sci. 50 (1995) 132-146.
[75] Woolford M.K., The significance of Propionibacterium spp, and Micrococcus lactylyticus to the ensiling process, J. AppI. Bacteriol. 39 (1975) 301-306.

[76] Woolford M.K., Microbiological screening of the straight chain fatty acids $\left(\mathrm{C}_{1}-\mathrm{C}_{12}\right)$ as potential silage additives, J. Sci. Food Agr. 26 (1975) 219-228.

[77] Woolford M.K., Aerobic deterioration of silage, Agric. Res. Council Rev. 4 (1978) 8-12.

[78] Woolford M.K., The Silage Fermentation, Marcel Dekker, New York, 1984.

[79] Woolford M.K., Aerobic deterioration of silage, in: Stark B.A., Wilkinson J.M. (Eds.), Developments in Silage 1986 - Silage and Animal Health, Chalcombe Publications, Marlow, UK, 1986.

[80] Woolford M.K., A Review: The detrimental effects of air on silage, J. Appl. Bacteriol. 68 (1990) 101-116.

[81] Woolford M.K., Bolsen K.K., Peart L.S., Studies on the aerobic deterioration of whole-crop cereal silages, J. Agr. Sci. 98 (1982) 529-535.

[82] Woolford M.K., Cook J.E., Investigations into the prevention of the aerobic deterioration of maize silage, in; Proc. XIIIth Internat, Grassland Cong, Leipzig, Section 9, 1977, pp. 232-237.

[83] Woolford M.K., Wilkins R.J., Preliminary experiments with simulated silage, J. Sci. Food Agr. 26 (1974) 141-148.

[84] Wyss U., Einsatz eines milchsaurebakterieimpfzusatzes bei grasssilage aus der sicht der konservierung, Landwirtschaft Schweiz 6 (1993) 202-207.

[85] Wyss U., Einsatz eines milchsaurebakterieimpfzusatzes bei maissilage aus der sicht der konservierung, Landwirtschaft Schweiz 6 (1993) 501-505.

[86] Wyss U., Honig H., Pahlow G., Einfluss von luftštrass und die wirkung von spezifischen zusatzen auf die aerobe stabilitat von grasswelksilagen, Wirtschaftseigene Futter 37 (1991) 129-141.

[87] Wyss U., Honig H., Pahlow G., The influence of air stress and the effect of specific additives on the aerobic stability of wilted grass silage, in: Workshop Proc, $15^{\text {th }}$ General Meeting of the European Grassland Federation, Netherlands Society for Grassland and Fodder Crops, Wageningen, the Netherlands, 1994, pp. 155-157. 